\title{
IGBP1 wt Allele
}

National Cancer Institute

\section{Source}

National Cancer Institute. IGBP1 wt Allele. NCI Thesaurus. Code C51259.

Human IGBP1 wild-type allele is located within Xq13.1-q13.3 and is approximately $33 \mathrm{~kb}$ in length. This allele, which encodes immunog lobulin-binding protein 1 , plays a role in both signal transduction and in B-cell activation and differentiation. 